\title{
Педіатрія
}

УДК 616.5-002-056.43-092]-053.2

®O. М. Мочульська

ДВНЗ «Тернопільський державний медичний університет імені I. Я. Горбачевського МОЗ Украӥни»

\section{ПОШИРЕНІСТЬ АТОПІЧНОГО ДЕРМАТИТУ В ДІТЕЙ, ОСОБЛИВОСТІ ЕТІОЛОГІЇ ТА ПАТОГЕНЕЗУ НА СУЧАСНОМУ ЕТАПІ}

ПОШИРЕНІСТЬ АТОПІЧНОГО ДЕРМАТИТУ В ДІТЕЙ, ОСОБЛИВОСТІ ЕТІЛОГІЇ ТА ПАТОГЕНЕЗУ НА СУЧАСНОМУ ЕТАПІ. Алергічні захворювання за останні роки досягнули розмірів епідемії, поширеність їх зростає в усьому світі. У структурі алергічних захворювань особливе місце посідає атопічний дерматит, оскільки він $є$ одним із найчастіших та перших проявів алергії, нерідко трансформується надалі в інші форми алергії, суттєво знижує якість життя дітей незалежно від віку, потребує тривалого та етапного лікування і реабілітації. Атопічний дерматит - мультифакторне захворювання, розвиток якого визначається дією генетичних і факторів зовнішнього середовища.

РАСПРОСТРАНЕННОСТЬ АТОПИЧЕСКОГО ДЕРМАТИТА У ДЕТЕЙ, ОСОБЕННОСТИ ЭТИОЛОГИИ И ПАТОГЕНЕЗА НА СОВРЕМЕННОМ ЭТАПЕ. Аллергические заболевания за последние годы достигли размеров эпидемии, распространенность их растет во всем мире. В структуре аллергических заболеваний особое место занимает атопический дерматит, поскольку он является одним из наиболее частых и первых проявлений аллергии, нередко трансформируется в дальнейшем в другие формы аллергии, существенно снижает качество жизни детей независимо от возраста, требует длительного и этапного лечения и реабилитации. Атопический дерматит - мультифакторное заболевание, развитие которого определяется действием генетических и факторов внешней среды.

PREVALENCE OF ATOPIC DERMATITIS IN CHILDREN, FEATURES OF ETIOLOGY AND PATHOGENESIS NOWADAYS. Allergic diseases in recent years reached scale of the epidemics, their prevalence is increasing worldwide. In the structure of allergic diseases atopic dermatitis occupies a special place, as it is one of the most common and first manifestation of allergy, is often transformed into other forms of allergy, significantly reduces the life quality of children regardless on age, needs long-term treatment and rehabilitation. Atopic dermatitis is a multifactorial disease, development of which is determined by influence of genetic and environmental factors.

Ключові слова: алергія, атопічний дерматит, етіологія, патогенез, алергени.

Ключевые слова: аллергия, атопический дерматит, этиология, патогенез, аллергены.

Key words: allergy, atopic dermatitis, etiology, pathogenesis, allergens.

Наша сучасність характеризується винятково тривожною ситуацією щодо зростання частоти алергічної патології [1, 2, 7, 22]. На думку провідних спеціалістів світу, в наш час алергія набула характеру світової епідемії $[8,10,21]$. Цей факт однаково стосується як економічно розвинених країн, так і країн, що розвиваються [32]. Протягом останнього десятиріччя кількість хворих з алергією у світі подвоїлася, в Україні вона виявляється майже в кожної четвертої дитини [8, 9]. Все частіше спостерігається полівалентна сенсибілізація, алергія стає поліорганною $[7,27,28]$. Згідно з прогнозами ВОО3, алергічні захворювання незабаром посядуть перше місце у структурі загальної патології. Так, за статистичними даними, за останні 30 років удвічі збільшилася частота бронхіальної астми, харчової алергії та атопічного дерматиту (АД). За інформацією ВООЗ, кожен п'ятий житель Землі страждає від алергічних чи псевдоалергічних реакцій [25, 26]. Першим проявом алергічної патології в дітей, як правило, є харчова алергія, що проявляється атопічним дерматитом [1, 3, 17, 22].

У структурі алергічних захворювань особливе місце посідає атопічний дерматит, оскільки він $€$ одним із найчастіших та перших проявів алергії; нерідко трансформується надалі в інші форми (бронхіальну астму, алергічний риносинусит); суттєво знижує якість життя дітей незалежно від віку; потребує тривалого та етапного лікування і реабілітації [6, 7, 27]. АД $є$ частиною атопічного синдрому, або атопії, до клінічних проявів якої також належать алергічний риніт (цілорічний і сезонний), алергічна бронхіальна астма, алергічний кон'юнктивіт та деякі алергічні захворювання шлунково-кишкового тракту [3, 5, 32]. АД надзвичайно поширений дерматоз, часто 3 тяжким перебігом. Як свідчать результати епідеміологічних досліджень, АД частіше виявляють у молодих людей, ніж у дорослих [20]. Так, його поширеність серед дитячого населення розвинених країн становить від 12 до $37 \%$, що значно перевищує цей показник серед дорослих $(0,2-2 \%)$ [15, 16]. Стрімке збільшення поширеності алергічних захворювань у дітей пов'язують зі змінами навколишнього середовища, способу життя і харчування, збільшенням алергенного навантаження на дитячий організм [24, 25]. Розповсюдженість АД у дітей першого року життя коливається від 9,0 до $28,5 \%$, у дітей $6-7$ років - від 5,5 до $30,8 \%, 13-14$ років - від 6,7 до $20,7 \%$ [3, 5, 32]. Дебют АД найчастіше має місце в ранньому дитячому віці: вперше проявляється до 6 місяців у $45 \%$ випадків, протягом першого року життя - в $60 \%$, до 5 років - у $85 \%$ випадків [13, 28].

Атопічний дерматит - хронічне алергічне захворювання шкіри, яке виникає, як правило, у ранньому дитячому віці, розвивається в осіб з генетичною 
схильністю до атопії, характеризується рецидивним перебігом, типовим висипанням із віковими особливостями локалізації і морфології вогнищ запалення, підвищенням рівня ІдЕ у сироватці крові й гіперчутливістю до специфічних (алергени) і неспецифічних подразників [23, 32]. АД сьогодні розглядається як системне захворювання, оскільки в патологічний процес втягується не лише шкіра, але й інші органи та системи [15, 20, 23, 32].

Атопічний дерматит $є$ мультифакторним захворюванням, розвиток якого визначається дією генетичних і факторів зовнішнього середовища $[9,10,19]$ Одну $з$ провідних ролей в етіології та патогенезі АД відіграє генетичний чинник. АД - спадкове захворювання $з$ полігенними формами успадкування. У 80 \% дітей, які страждають від АД, є обтяжена щодо алергії спадковість, частіше по материнській лінії (69$70 \%$ ). Ризик розвитку АД становить 60-80\%, якщо і батько, і мати страждають від атопії, 45-50 \% - якщо страждає один 3 батьків і 10-12 \% - у здорових батьків. Обговорюється можливість участі 26 генів у розвитку атопії [2, 32]. Для багатьох генів установлений зв'язок з тією чи іншою ознакою атопії та визначені локалізації. Вважають, що в основі атопії лежать спадково зумовлена дисфункція імунної системи (гіпофункція вилочкової залози), уроджений імунодефіцит механізмів «клітинної медіації», безпосередньо Т-лімфоцитів, схильність до підвищеного біосинтезу імуноглобулінів (збільшений вміст у крові та тканинах реагінових антитіл класу Е), що спричиняє ранню сенсибілізацію до різних антигенів [3, 5, 18, 19, 29]. Екзогенні фактори, що викликають загострення АД, називають тригерами. Виходячи 3 різних патогенетичних механізмів АД, виділяють алергенні (харчові, побутові, пилкові, епідермальні, грибкові, бактеріальні, вакцинні) й неалергенні (психоемоційні навантаження, метеорологічні, тютюновий дим, харчові добавки, ксенобіотики, полютанти) тригери [3, 5, 32].

До етіологічних чинників розвитку АД належать алергени, які можуть бути як неінфекційного (харчові, інгаляційні, лікарські), так і інфекційного походження (бактерії, грибки, віруси). Розвиток гіперчутливості до таких алергенів відбувається при їx потраплянні в організм дитини ентеральним, інгаляційним або контактним (через шкіру) шляхами, інколи парентерально [3, 11, 27, 32].

У ранньому дитячому віці (до 3 років) провідними $€$ харчові тригери, що пов'язано з анатомо-фізіологічними особливостями шлунково-кишкового тракту дитини. Незрілість і недостатня диференціація функцій різних відділів шлунково-кишкового тракту сприяють тому, що харчова алергія в дітей розвивається частіше, ніж у дорослих. Харчову алергію вважали «стартовою сенсибілізацією» у виникненні поширеної алергії [7, 27]. Контакт з екзоалергенами - важливий поштовх до розвитку сенсибілізації, а наступні контакти 3 ними сенсибілізованих дітей $€$ фактором ризику як виникнення загострень респіраторної алергії, так і персистенції її проявів [7, 18, $27,30,31]$. Надалі харчова алергія може спричинити розвиток не тільки атопічного дерматиту, але й алер- гічного риніту, бронхіальної астми $[25,28]$. Такий перехід одного алергічного захворювання в інше називають «алергічним маршем» [26]. Вважають, що найбільш вираженою алергенною активністю володіють харчові продукти білкового походження (тваринні й рослинні білки). Жири, вуглеводи, мікроелементи частіше викликають псевдоалергічні реакції. До найбільш поширених харчових алергенів належать кава, какао, шоколад, цитрусові, полуниця, суниця, яйця, м'ясо тварин і птахів, мед, риба, ікра, краби, раки, молоко, морква, буряк, томати, гречана крупа, злаки, бобові, горіхи [3, 5, 10, 32]. 3 віком спектр харчових алергенів змінюється за якістю і за частотою виявлення [3, 27, 28].

Після 3 років життя роль харчових алергенів у генезі АД знижується, а інгаляційних (кліщових, бактеріальних, грибкових, вірусних, епідермальних, пилкових) - збільшується. Від 3 до 7 років етіологічне значення харчових алергенів зберігається, але в цей період зростає значення побутових, кліщових та пилкових алергенів; розширюється спектр причиннозначущих алергенів (полівалентна алергія) [26, 27]. 3 пилкових алергенів спочатку формується сенсибілізація до алергенів пилку злакових трав - зумовлено наявністю «перехресних» (спільних) алергенів до харчових алергенів і пилку злаків [3, 5, 29, 32].

У дітей, старших 5-7 років, у формуванні АД значно зростає роль інгаляційних алергенів. Серед них причиною розвитку АД можуть бути побутові (домашній пил, бібліотечний пил), епідермальні алергени (вовна, пух, епідерміс тварин, птахів, наприклад перо подушок, шерсть кішки, собаки та інших тварин), пилок рослин (дерев, злакових, складноцвітих) [26]. У дітей старшого віку провідне значення мають інгаляційні алергени, а харчові залишаються значними лише в невеликої кількості дітей. 3 інфекційних алергенів найбільшу роль відіграють стафілокок (Staphylococcus aureus), грибкова інфекція (Trichophyton rubrum, Malasseria furfur, Pityrosporum orbiculare, Pityrosporum ovale) [3, 5, 11, 32]. Досить часто причинними факторами розвитку і загострення АД у дітей стають медикаменти (антибіотики в $90 \%$ випадків, сульфаніламідні препарати, місцеві анестетики, нестероїдні протизапальні препарати, вітаміни групи В), особливо після їх неадекватного призначення або безконтрольного використання, і досить часто причинами розвитку АД у дітей $є$ глистні інвазії $[9,10]$. Певну роль у розвитку АД відіграють інфекція, емоційні чинники, підвищене потовиділення, тютюновий дим, гормональні фактори, зміни взаємовідношення холінергічної та симпатико-адреналової систем, стабільність цитоплазматичних мембран, зумовлена станом вільнорадикального окиснення ліпідів, активація метаболізму арахідонової кислоти 3 підвищенням синтезу лейкотрієнів, простагландинів $[15,16]$. Особливу увагу привертає роль інфекційних агентів, що можуть змінити характер імунної відповіді організму. Однак через складність патогенезу АД літературні дані щодо впливу бактеріальних патогенів протилежні.

Патогенетичну основу захворювання складають алергічне запалення та гіперреактивність шкіри, а 


\section{Педіатрія}

також порушення бар'єрної функції епідермісу за рахунок генетично детермінованого дефекту ліпідного метаболізму кератиноцитів [3, 5, 32]. В основі патогенезу атопічного дерматиту в більшості дітей лежать IgЕ-опосередковані (атопічні) імунопатологічні реакції. Секретований у шкірі $\operatorname{lgE}$ фіксується на рецепторах мастоцитів (сенсибілізація) [8, 17, 19]. Водночас у 10-30 \% хворих при даній патології підвищений рівень IgE не реєструється. Очевидно, в таких пацієнтів патогенетичним підґрунтям атопічного дерматиту є інші імунні та неімунні (псевдоалергічні) механізми запалення [1, 2, 7, 22]. Патогенез багато в чому визначається механізмами неадекватної імунної реактивності, зумовленої розвитком гіперчутливості сповільненого та негайного типів [9, 12].

Протягом останніх років суттєво розширилися уявлення щодо ролі шкірних покривів у формуванні імунної відповіді на алерген. Шкірні покриви при атопічному дерматиті $\epsilon$ не тільки «органом-мішенню», але й органом, що бере активну участь у формуванні атопії. Ініціація імунної відповіді здійснюється в асоційованій зі шкірою лімфоїдній тканині (SALT - skin associated lymphoid tissue) [9, 10]. Концепція лімфоїдної тканини, асоційованої зі шкірою SALT - під цим терміном були об'єднані антигенопрезентуючі клітини епідермісу, тропні до епідермісу Т-клітини, кератиноцити й регіональні лімфовузли; в дермі - опасисті клітини, макрофаги, В-лімфоцити, ендотелій кровоносних i лімфатичних судин. Основними антигенопрезентуючими клітинами шкіри є дендритні клітини (клітини Лангерганса), саме вони ініціюють імунну відповідь шляхом розпізнавання антигену, його захоплення (фагоцитоз, адсорбційний рецепторопосередкований ендоцитоз, макропіноцитоз), процесинг (попереднє розщеплення) і презентацію імунокомпетентним клітинам [1, 2, 7, 9, 17, 22]. Тимусний стромальний лімфопоетин, який продукується кератиноцитами хворих на атопічний дерматит у великій кількості, сприяє ініціації імунної відповіді, індукуючи міграцію клітин Лангерганса в лімфатичні вузли $[14,18]$. Зі шкіри запальні активовані дендритні клітини мігрують у регіональні лімфовузли, де відбуваються подальша взаємодія з Т-лімфоцитами хелперами (презентація антигену), взаємодія з В-лімфоцитами (активація і перетворення їх у плазмоцити, синтез $\mathrm{lgE}$ ). У подальшому антитіла та сенсибілізовані лімфоцити повертаються до шкіри і призводять до реалізації імунної запальної відповіді, що проявляється клінічно симптомами АД [1, 2, 8, 17, 22]. У разі повторного потрапляння антиген розпізнають фіксовані на опасистій клітині антитіла, відбувається ії̈ активація 3 подальшим вивільненням преформованих медіаторів алергії - гістаміну, серотоніну, кінінів, які зумовлюють розвиток ранньої фази алергійної відповіді [3, $5,12,32]$.

Клітини Лангерганса виконують важливу антигенопрезентуючу функцію, спрямовану на індукцію імунної відповіді проти чужорідного антигену. Результат презентації антигену Т-клітинам визначається за конвергенцією їх сигналів. Експресія клітинами Лангерганса високоафінних рецепторів для IgE в осіб, схильних до атопії, забезпечує активну презентацію
Т-лімфоцитам навіть мінімальної кількості антигену [14]. Цитокіни SCF, TNF-a i TGF передають сигнали 3 активованих клітин Лангерганса на Т-лімфоцити, ініціюючи ТЬ^-поляризацію. Патерн TII2 пов'язаний з підвищеною секрецією В-лімфоцитами $\lg$ та $\lg$ Е-опосередкованими алергічними реакціями, а також із переважанням секреції IL-4, IL-5 і IL-13 [14, 18].

Центральна імунологічна толерантність підтримується в тимусі, периферична - у регіональних лімфовузлах $[3,5,32]$. На даний час доведено зв'язок змін клітинно-опосередкованого і гуморального імунітету у хворих на АД з порушенням тимусного дозрівання лімфоцитів-супресорів [14, 18].

Визнана Th1/Th2 концепція атопічного дерматиту. Провідним імунопатологічним механізмом розвитку АД є зміна співвідношення між Т-хелперами першого (Th1) і Т-хелперами другого (Th2) порядків на користь останніх, що призводить до зміни профілю їх цитокінової секреції, підвищеного продукування загального та специфічного $\mathrm{lg}$ Е-антитіл, які фіксуються за допомогою Fc-фрагмента до специфічних рецепторів на мембранах опасистих клітин та базофілів [4, $12,14]$. Популяція клітин пам'яті при стимуляції антигеном може направити Тh-клітинну відповідь організму по Th 1 - або Th2-шляху. Перший тип імунної відповіді спостерігається у неатопіків, другий - при наявності атопії. Клітини Th1 синтезують IL-2, INF-y, TNF-a та інші - ці цитокіни зумовлюють реакції сповільненого типу. Клітини Th2 виробляють IL-4, IL-5, $\mathrm{IL}-10$, IL-13, які відповідальні за розвиток атопічної реактивності. Цитокіни, синтезовані клітинами Th2, перебувають у динамічній опозиції до клітин Th1 i навпаки [1, 3, 5, 32].

У фазу хронізації процесу при АД домінуюче значення мають ТЬі1 і їх цитокіни [4, 14]. Хронізація алергічного запалення супроводжується змінами цитокінового профілю [3, 14, 18, 32]. Основні медіатори IL-6, IL-8, INF-y, а при тривалому перебігу шкірного процесу - також IL-3 і GM-CSF. Для хронічного запалення характерна інфільтрація шкіри нейтрофілами, еозинофілами, макрофагами. Збільшується кількість опасистих клітин, які синтезують і секретують IL-4, що ініціює диференціювання та проліферацію Th2-лімфоцитів.

3 імунологічних механізмів гіперчутливості в шкірі реалізуються всі відомі типи реакцій: І тип (реагінові, IgЕ-залежні), II тип (цитотоксичні), III тип (імунокомплексні), IV тип (клітинно-опосередковані), Утип (стимулюючі реакції гіперчутливості) [2, 5, 11, 32]. Отже, при атопічному дерматиті в шкірі можуть бути реалізовані не тільки алергічні реакції негайного типу (IgEзалежні), а й клітинно-опосередковані реакції гіперчутливості сповільненого типу (Т-залежні). Дисбаланс Th1- i ^2-лімфоцитів, підвищена антигенопрезентуюча активність клітин Лангерганса, посилена дегрануляція опасистих клітин, що призводить до надлишкового продукування $\mathrm{lgE}$, займають найважливіше місце в патогенезі атопічного дерматиту [3, 5, 11, 14, 32]. Тісна взаємодія між клітинами, які беруть участь у розвитку алергічного запалення і ремоделюванні (структурних змінах) епітеліального шкірного бар'єру, зумовлює пролонгування імунної відповіді й ви- 
значає безперервно-рецидивний перебіг шкірного процесу [32].

У патогенезі атопічного дерматиту мають значення також псевдоалергічні реакції [3, 32]. В основі цих реакцій лежать підвищені лібрація, утворення гістаміну або знижена його інактивація, що призводить до зростання рівня гістаміну в крові й тканинах викликає класичні клінічні прояви [1, 2, 5, 11].

ВИСНОВКИ. У структурі алергічних захворювань особливе місце посідає атопічний дерматит. Клінічна його маніфестація є результатом взаємодії генетичних факторів, перинатальних та постнатальних фак- торів ризику, порушень імунної системи, анатомофізіологічних особливостей шкіри та дії внутрішніх і зовнішніх чинників (тригерів). Шкіра при атопічному дерматиті - це не тільки «дзеркало атопії», але й «entry point» (вхідні ворота) для наступних системних алергічних захворювань, атопічного маршу.

ПЕРСПЕКТИВИ ПОДАЛЬШИХ ДОСЛІДЖЕНЬ ПОлягають у подальшому детальному вивченні особливостей етіології і патогенезу атопічного дерматиту в дітей для проведення ефективних лікувально-профілактичних заходів з метою зменшення рівня захворюваності на алергодерматози.

\section{СПИСОК ЛІТЕРАТУРИ}

1. Аряев Н. Л. Атопический дерматит в практике педиатра / Н. Л. Аряев, В. А. Клименко, В. А. Феклин - K., 2007. - 32 c.

2. Аряев М. Л. Атопічний дерматит у дітей / М. Л. Аряев, В. А. Клименко, А. І. Кожем'яка. - К., 2006. $88 \mathrm{c}$.

3. Атопічний дерматит у дітей / [М. Л. Аряев, В. А. Клименко, А. І. Кожем'яка та ін.]. - К., 2005. $88 \mathrm{c}$.

4. Атопический дерматит у детей: оптимизация противозудной терапии / Т. Р. Уманець, В. Ф. Лапшин, Л. М. Тжердж, С. Ю. Матвеева // Перинатология и педиатрия. - 2013. - № 3 (55). - С. 43-47.

5. Балаболкин И. И. Лечение аллергических болезней у детей / И. И. Балаболкин. - М. : ООО «Медицинское информационное агенство», 2008. - 352 с.

6. Банадига Н. В. Атопічний дерматит з позиції педіатра / Н. В. Банадига // Здоровье ребенка. 2008. - № 4. - С. 86-89.

7. Беш Л. В. Алергічний марш: перспективи профілактики і прогнозу / Л. В. Беш. - Львів : Каменяр, 2010. - 68 c.

8. Беш Л. В. Атопічний дерматит у дітей / Л. В. Беш // Здоров'я України. - 2009. - Тематичний номер, алергологія. - С. 21-23.

9. Беш Л. В. Атопічний дерматит у дітей: аналіз діагностичних і тактичних помилок / Л. В. Беш // Здоров'я України. - 2013. - Тематичний номер, алергологія. - С. 52-53.

10. Беш Л. В. Атопічний дерматит у дітей: аналіз діагностичних і тактичних помилок / Л. В. Беш // Здоров'я України. - 2012. - № 3, вересень. - С. 34-35.

11. Больбот Ю. К. Аллергия - болезнь цивилизации. Механизмы развития заболевания и подходы к терапии / Ю. К. Больбот // Здоровье ребенка. 2009. - № 2. - С. 17.

12. Буянова О. В. Нові підходи до лікування атопічного дерматиту / О. В. Буянова, О. Я. Василюк // Український журнал дерматології, венерології, косметології. - 2005. - № 2, червень. - С. 43-46.

13. Дутчак Г. М. Особливості перебігу атопічного дерматиту у дітей / Г. М. Дутчак, О. Б. Синоверська // Здоровье ребенка. - 2011. - № 6. - С. 33-35.
14. Дюбкова Т. П. Современное представление о патогенезе атопического дерматита у детей / Т. П. Дюбкова // Медицинские новости. - 2006. № 12. - С. 28.

15. Зайков С. В. Атопічний дерматит у дітей / С. В. Зайков // Дитячий лікар. - 2010. - № 2, квітень. - C. 51-58.

16. Зайков С. В. Діагностика псевдоалергічних та істинних алергічних реакцій / С. В. Зайков // Новости медицины и фармации. - 2011. - Тематичний номер, алергологія і пульмонологія. - С. 380.

17. Зубаренко А. В. Атопический дерматит, концепция эффективной терапии / А. В. Зубаренко, 0. А. Портнова // Здоровье ребенка. - 2009. - № 3. - C. 103-108.

18. Зубаренко А. В. Атопический дерматит: современные взгляды на этиопатогенез, клинику и диагностику заболевания / А. В. Зубаренко,О. А. Портнова // Здоровье ребенка. - 2008. - № 6. - С. 15-18.

19. Качук Ю. В. Опыт использования препаратов магния в терапии атопического дерматита / Ю. В. Качук, К. С. Шмелькова // Новости медицины и фармации. - 2009. - Тематический номер, дерматология и косметология. - С. 276.

20. Коган Б. Г. Атопічний дерматит: акцент на безпечності лікування / Б. Г. Коган // Український журнал дерматології, венерології, косметології. - 2013. - № 1 (48). - С. 81-89.

21. Корицька І. В. Специфічна імунотерапія / 1. В. Корицька // Новости медицины и фармации. 2008. - Тематичний номер, алергологія і пульмонологія. - С. 246.

22. Ласиця О. Л. Алергологія дитячого віку / О. Л. Ласиця, Т. С. Ласиця, С. М. Недільська. - К. : Книга плюс, 2004. - С. 80-106.

23. Про затвердження Протоколів діагностики та лікування алергологічних хвороб у дітей : наказ МОЗ України № 767 від 27.12.2005 р. / Міністерство охорони здоров'я України. - К., 2005. - 35 с.

24. Няньковський С. Л. Атопічний дерматит з позиції педіатра / С. Л. Няньковський, О. С. Івахненко // Здоровье ребенка. - 2009. - № 3. - С. 1819. 


\section{Педіатрія}

25. Няньковський С. Л. Особливості профілактики і дієтотерапії харчової алергії у дітей раннього віку / С. Л. Няньковський, О. С. Івахненко // Здоровье ребенка. - 2010. - № 6. - С. 27-29.

26. Няньковський С. Л. Особливості профілактики харчової алергії у дітей / С. Л. Няньковський, О. С. Івахненко, Д. О. Добрянський // Здоровье ребенка. - 2009. - № 3. - С. 18.

27. Охотникова Е. Н. «Аллергический марш»: связь поколений и эскалация аллергии у детей / Е. Н. Охотникова // Клиническая иммунология, аллергология, инфектология. - 2008. - № 4 (15), червень. - С. 44-52.

28. Охотникова Е. Н. Механизмы формирования и клинические особенности течения «аллергического марша» у детей / Е. Н. Охотникова // Здоров'я України. - 2010. - Тематичний номер, квітень. - С. 16-17.
29. Охотнікова О. М. Педіатричні аспекти атопічного дерматиту / О. М. Охотнікова // Український журнал дерматології, венерології, косметології. 2006. - № 4, грудень. - С. 27-33.

30. Охотникова Е. Н. Профилактика аллергии у детей: возможна ли она? / Е. Н. Охотникова // Здоров'я України. - 2010. - Тематичний номер, червень. - С. 26-29.

31. Охотнікова О. М. Профілактика алергії у у дітей: сучасні можливості та перспективи / О. М. Охотнікова // Дитячий лікар. - 2011. - № 2. - С. 26-27.

32. Педіатрія - національний підручник / [О. Є. Абатуров, Ю. Г. Антипкін, Г. В. Бекетова та ін.] ; за ред. В. В. Бережного. - К. : Міністерство охорони здоров'я України, асоціація педіатрів України, 2013. - T. 1. - С. 498-519.

Отримано 11.02.15 